\title{
Effects of long-term endurance exercise and Salvia miltiorrhiza vinegar on body composition and insulin resistance in high fat diet-induced obese rats
}

\author{
Kijin Kim ${ }^{1 *}$, Su-Ryun Jung ${ }^{1}$, Na-young Ahn ${ }^{1}$, Ju-sik Park ${ }^{1}$, Young-Sik Ju ${ }^{1}$, \\ Sung-Wook Kim ${ }^{1}$, Gyu-Ho Lee ${ }^{1}$, Mi-Yeon Kim ${ }^{2}$, Yong-Jin Jeong ${ }^{2,3}$ \\ ${ }^{1}$ Department Physical Education, Keimyung University, Daegu 42601, Korea \\ ${ }^{2}$ KMF Co., Ltd., Daegu 41065, Korea \\ ${ }^{3}$ Department of Food Science and Technology, Keimyung University, Daegu 42601, Korea
}

\section{장기간의 지구성 운동과 단삼식초 섭취가 고지방식 유도 비만 흰 쥐의 신체구성과 인슐린 저항성에 미치는 영향}

\author{
김기진 $^{1 *} \cdot$ 정수련 $^{1} \cdot$ 안나영 $^{1} \cdot$ 박주식 $^{1} \cdot$ 주영식 $^{1} \cdot$ 김성욱 $^{1} \cdot$ 이규호 $^{1} \cdot$ 김미연 $^{2} \cdot$ 정 용진 $^{2,3}$ \\ ${ }^{1}$ 계명대학교, ${ }^{2}$ (주)케이엠에프 , ${ }^{3}$ 계명대학교 식품보건학부
}

\begin{abstract}
The purpose of this study was to examine the effects of long-term endurance exercise and salvia miltionhiza vinegar on body composition and insulin resistance of high-fat diet $(30 \%$ carbohydrate, $50 \%$ fat and $20 \%$ protein) induced obese rats. After 8 weeks of high fat diet (50\% of total calories), rats were divided into 4 groups (sedentary group, $\mathrm{n}=10$; exercise group, $\mathrm{n}=10$; Salvia miltiorrhiza vinegar group, $\mathrm{n}=10$; exercise+Salvia miltiorrhiza vinegar group, $\mathrm{n}=10$ ) for 8 weeks. Body weight, body composition, diet intake volume, oral glucose tolerance test, plasma total cholesterol were measured. The results showed that Salvia miltiorrhiza vinegar plus endurance exercise training for 8 weeks significantly improved body weight control, visceral fat weight, and insulin resistance. However, only Salvia miltiorrhiza vinegar treatment did not significantly improve body composition and insulin resistance. In addition, there was no additive by the combination of Salvia miltiorrhiza vinegar and endurance exercise in insulin, body fat, and total cholesterol. The reduction of body fat, glucose, insulin and cholesterol by combination was resulted from the exercise. These results suggest that Salvia miltiorrhiza vinegar has slight effect on anti-hyperglycemia and anti-obesity.
\end{abstract}

Key words : Salvia miltiorrhiza, endurance exercise, vinegar, body composition, insulin resistance

\section{서 론}

제 2형 당뇨병은 인슐린 저항성(insulin resistance, IR)으 로 인한 탄수화물, 단백질 및 지방 대사의 기능 저하를 특징 으로 하는 대사성 질환으로서 당뇨병의 가장 흔한 유형이다

*Corresponding author. E-mail : kjk744@kmu.ac.kr

Phone : 82-53-580-5256, Fax : 82-53-580-5314

Received 1 June 2017; Revised 17 July 2017; Accepted 28 July 2017.

Copyright (c) The Korean Society of Food Preservation. All rights reserved.
(1,2). 지난 수십 년 동안 제 2형 당뇨병의 유병률은 전 세계 적으로 현저히 증가하였으며, 부적절한 식습관과 신체활동 으로 인해서 앞으로 더욱 증가 할 것으로 예상되고 있다 $(3,4)$. 따라서 제 2형 당뇨병 치료를 위한 다양한 방법들이 모색되어오고 있는데, 현재 sulfonylureas, non-sulfonylurea secretagogues, a-glucosidase inhibitors, thiazolidinedione, glucagon-like peptide-1 analog, dipeptidylpeptidase-4 inhibitors 등과 같은 약물이 주로 당뇨병 처치를 위한 약물로 사용되 어오고 있다. 그러나 이러한 약물들은 부작용과 혈당 조절 실패율이 높게 나타나기 때문에 $(1,5)$ 그 대처방안이 요구되 고 있다. 따라서 제 2형 당뇨병 치료제로써 합성 약물보다 
독성이 적고 부작용이 적은 천연물을 개발하기 위한 관심이 점차적으로 높아지고 있다 $(6,7)$.

단삼(Danshen, Salvia miltiorrhiza Bunge)은 꿀풀과 다년 생 식물로서 적삼, 자단삼, 대홍포, 활혈근 등으로도 불리며, 뿌리가 붉어서 단삼이라고도 한다(8). 본초강목 및 동의보 감에 의하면 단삼은 항암효과는 물론 심혈관 질환, 염증성 질환, 간 기능 저하 관련 질환, 생리불순, 생리통, 어혈성 심복부동통, 불면증, 피부발진 등의 치료에 널리 사용되어 온 것으로 기록되어 있다(9-12). 생약의 단삼은 뿌리를 말린 것으로 특이한 냄새와 약간 쓴맛이 나며, 단삼의 유효 성분 은 tanshionine, cryptotanshionone, miltionone, dihydrotanshion, salvianolic acid, lithospermic acid B 등이 포함되어 있다(13). 특히 salvianolic acid $\mathrm{B}(\mathrm{Sal} \mathrm{B})$ 는 단삼 내 주된 폴리페놀 화합물질로서 심혈관 질환의 치료제로 주로 사용되고 있다 (14-16). 최근 연구에 따르면 Sal B는 인슐린 저항성과 비만 및 제 2형 당뇨병 치료를 위한 잠재적인 치료제로서의 기능 을 가지고 있는 것으로 보고되었다(17-20). Sal B 또는 Salvia miltiorhiza 추출물은 혈당 조절력을 개선시키고, 이 상 지질 혈증 및 고지방식 또는 스트렙토조토신 유발 2형 당뇨병 쥐의 골격근 내 인슐린 감수성을 향상시키는 것으로 나타났다 $(17,19)$. 또한 Sal B는 peroxisome proliferatoractivated receptor gamma(PPARy) 매개성 지방 형성을 억제 하여 고지방식이로 유도된 비만 C57BL/6J 쥐의 혈중 지질 농도를 조절하고 체지방량을 감소시키는 것으로 보고되었 다(18).

실제 비만과 인슐린 저항성의 개선에 가장 효과적인 방 법은 지구성 운동과 같은 활발한 신체적 활동을 들 수 있다. 그러나 비만한 제 2형 당뇨병 환자들이 규칙적인 운동을 통해서 안정적으로 혈당을 조절한다는 것은 현실적인 어려 움이 있다. 따라서 본 연구는 현실적인 대안을 모색해 보고 자 고지방식 유도 비만 흰쥐를 대상으로 단삼의 천연물 섭취와 중강도의 지구성 운동을 실시하여 비만 및 혈당 조절에 미치는 영향을 비교 분석해 보고자 한다. 또한 단삼 의 섭취 형태는 발효식초의 형태로서 경구 투여방식을 사용 하고자 한다. Yun 등(8)은 일반 인삼보다 식초로 가공된 인삼의 섭취가 대사성 증후군의 개선에 더욱 효과적인 것으 로 보고하였다. 이러한 방법은 식초의 주성분인 아세트산 (acetic acid)을 조직 내로 빠르게 흡수되도록 하며, AMPactivated protein kinase(AMPK)의 활성화를 유도함으로써 복부 지방과 간 조직 내 지질 축적을 예방하기 때문이다 (21). 또한 건강식품으로서 식초의 섭취량은 꾸준히 증가하 고 있으며, 다른 약제의 형태보다 경제적, 심리적 부담 없이 섭취할 수 있다는 장점이 있다. 마지막으로 단삼식초와 중 강도의 지구성 운동의 복합처치 시 단독처치와 비교해 부가 적인 개선효과가 나타나는지를 관찰함으로서 대사성 증후 군의 개선 및 치료에 도움을 줄 수 있는 효과적인 방법을 제공하고자 한다.

\section{재료 및 방법}

연구대상

10주령 수컷 Wistar 흰쥐(weight, 300-330 g) 40마리를 대상으로 1 주간의 환경적응기간을 거친 후 8 주간 고지방식 처치로 비만을 유도하였다. 이후 4 집단, 즉 좌업군(sedentary group; Sed, $n=10$ ), 운동군(exercise group; $\mathrm{Ex}, \mathrm{n}=10$ ), 단삼식 초섭취군(Salvia miltiorrhiza inegar group; SV, $\mathrm{n}=10$ ), 운동 군+단삼식초섭취 복합처치군 $(\mathrm{EV}, \mathrm{n}=10)$ 등으로 무선, 배정 하여 총 8 주간 운동 및 식이처치를 실시하였다. 흰쥐는 한 케이지 $(20.7 \times 35 \times 17 \mathrm{~cm})$ 에 2 마리씩 사육하였으며, 사육실 의 온도는 $21^{\circ} \mathrm{C}$ 로 유지하였다. 명기와 암기를 각각 12 시간 으로 조절하였으며, 암기는 오전 7:00시에서 오후 7:00로 조절하였다. 실험기간 동안 체중과 사료섭취량은 매일 측 정하였다. 본 동물실험계획서는 (재)대구테크노파크 바이 오헬스융합센터 동물실험윤리위원회의 심의를 통과하였 다(승인번호: BHCC-IACUC-2015-09).

\section{고지방식의 조성}

고지방식이는 총 열량에 대해서 carbohydrate $30 \%$, fat $50 \%$, protein $20 \%$ 가 되도록 하였으며, 세부내용은 1,000 $\mathrm{g} / \mathrm{kg}$ 기준 casein $245.0 \mathrm{~g}$, sucrose $200.0 \mathrm{~g}$, corn starch 85.0 $\mathrm{g}$, cellulose $58.0 \mathrm{~g}$, choline bitariate $3.0 \mathrm{~g}$, L-cystine $3.5 \mathrm{~g}$, maltodextrin $115.0 \mathrm{~g}$, lard $195.0 \mathrm{~g}$, soybean oil $30.0 \mathrm{~g}$, vitamins(19 g/kg AIN-93G-VX no. 94047), minerals(43 g/kg AIN-93G-MK mix no. 94046), calcium phosphate 3.4 g, Red food color $0.1 \mathrm{~g}$ 등을 혼합하여 사용하였다(22). 식수와 사료 의 섭취는 자유롭게 하였다.

\section{단삼식초 및 운동처치}

단삼식초섭취군은 Lee 등(23)의 방법을 일부 수정하여 단삼식초(산도 $4.2 \pm 0.01 \%$, 알코올 함량 $0.2 \pm 0.01 \%, \mathrm{pH}$ $3.4 \pm 0.00$, 당도 $4.7 \pm 0.01{ }^{\circ} \mathrm{Brix}$, (주)케이엠에프 제공)를 1 일 $7 \mathrm{~mL} / \mathrm{kg}$ 경구 투여 하였다. 나머지 집단은 경구 투여에 대한 스트레스를 동일하게 주기 위해서 동일한 양의 생리식 염수를 경구 투여 하였다. 운동 프로토콜은 Ivy 등(24)의 방법을 부분적으로 수정하여 적용하였다. 전동식 실험동물 용 트레드밀(Quinton Instrument, Seattle, WA, USA)을 이용 하여 중강도로 주 3회 트레드밀 달리기를 실시하였다. 초기 1 주간 운동 프로그램의 적응을 위해 $10 \mathrm{~m} / \mathrm{min}$ 의 속도와 경사도 $0^{\circ}$ 로 5 분간 실시한 후 점증적으로 트레드밀 속도와 경사도, 시간을 증가시켜 2 주부터는 경사도 $8^{\circ}$ 에서 20 $\mathrm{m} / \mathrm{min}$ 의 속도로 30 분간 달릴 수 있도록 하여 실험 종료 시까지 운동 수준을 유지하였다. 모든 처치는 오전 9:00-10:00 사이에 실시하였으며, 운동과 단삼식초섭취의 혼합 처치 시에는 운동 60 분 전 단삼식초를 섭취시킨 다음 운동을 실시하였다. 


\section{경구당 부하검사}

지구성 운동과 단삼식초가 비만 흰쥐의 혈당조절 효과에 미치는 영향을 검증하기 위해서 경구당 부하검사를 실시하 였다. 8주간의 처치 후 last-bout exercise effect를 배제하기 위해 48시간 휴식하고, 12 시간 금식시켰다. 꼬리를 통해서 안정 시 혈액을 채취한 후 $50 \%$ 포도당 용액을 $1 \mathrm{~g} / \mathrm{kg}$ 으로 경구 투여 하였다. 이후 $15,30,60$ 분에 꼬리로 부터 300 $\mu \mathrm{L}$ 의 혈액을 채취하였다. 채취된 혈액은 항 응고 처리(5 $\mu \mathrm{L}$ 헤파린)한 후 원심 분리하여 $(1,500 \times g, 15$ 분) 혈장만을 추출한 다음 분석 전 까지 $-80^{\circ} \mathrm{C}$ 에서 보관하였다. 혈액 채취 가 끝난 흰쥐들은 소실된 혈장을 보충시키기 위해서 $0.9 \%$ 생리식염수 용액 $(2.5 \mathrm{~mL})$ 을 피하에 주입하였다.

\section{조직적출 및 혈액채취}

총 8 주간의 처치 후 12 시간 금식을 실시하고 pentobarbital $\operatorname{sodium}(5 \mathrm{mg} / 100 \mathrm{~g}$ of body mass)으로 마취하여 소 동물용 DEXA(DSC-3000, Aloka, Tokyo, Japan)를 이용하여 신체구 성을 측정하였다. 이 후 복강을 열어 복부동맥에서 혈액 $5 \mathrm{~mL}$ 을 채취하고, 12 시간 냉장 보관하여 serum을 분리한 후 분석 전 까지 $-20^{\circ} \mathrm{C}$ 에서 보관하였다. 혈액 채취 후 부위 별 체지방(epididymal, mesenteric, retroperitoneal fat pad)을 적출하고 무게를 측정하였다.

\section{혈 액분석}

혈당과 혈중 인슐린 수준은 꼬리에서 수집된 혈액을 항 응고 처리하여 얻은 혈장을 이용하여 분석하였다. 혈당은 자동혈당측정기(YSI 2300 STAT plus, YSI, USA)로 측정하 였으며, 혈중 인슐린 농도는 ELISA Kit(Diagnostic Products Corporation, California, LA, USA)를 이용하여 분석하였다. 복강에서 채취한 혈액은 혈청을 분리하여 Sigma사의 ELISA kit(kits 352, St. Louis, MO, USA)을 이용하여 효소분 석법으로 총콜레스테롤(total cholesterol, TC) 수준을 분석 하였다.

\section{자료처리 방법}

모든 자료는 SigmaPlot 12.0 통계프로그램을 이용하여 각 그룹별 평균과 표준오차(Mean $\pm \mathrm{SE})$ 를 산출하였다. 측정 변인들에 대한 그룹 간 차이를 분석하기 위하여 One-way ANOVA를 실시하였으며, 경구당 부하검사 결과는 처치와 시간에 따른 유의차를 분석하기 위해서 Two-way repeated ANOVA를 실시하였다. 사후검정은 Tukey 방법을 이용하 였으며, 통계적 유의수준은 $\mathrm{p}<0.05$ 로 하였다.

\section{결과 및 고찰}

\section{신체구성 및 1 일 식이섭취량}

8 주간의 지구성 운동군 또는 단삼식초섭취군은 고지방
식 유도 비만 흰쥐의 체중에 유의한 영향을 미치지 않았다. 그러나 지구성 운동과 단삼식초섭취의 복합처치군의 체중 은 다른 3 집단에 비해서 유의하게 감소하였다 $(\mathrm{p}<0.05)$. 체지방과 제지방량은 지구성 운동군과 좌업군 간에 유의한 차이가 나타나지 않았으나, 단삼식초섭취군은 다른 3집단 에 비해서 체지방량이 유의하게 증가하였으며, 제지방량은 유의하게 감소한 것으로 나타났다(p<0.05). 그러나 지구성 운동과 단삼식초섭취의 복합처치군의 체지방과 제지방량 은 좌업군과 운동군과 비교해서 유의한 차이가 나타나지 않았다(Fig. 1). 신체분포 부위에 따른 체지방량을 측정한 결과, 8 주간의 지구성 운동군은 epididymal, mesentric fat $\mathrm{pad}$ 양이 유의하게 감소하였다 $(\mathrm{p}<0.05)$. 그러나 retroperitoneal fat pad에서는 지구성 운동의 효과가 나타나지 않았다. 이

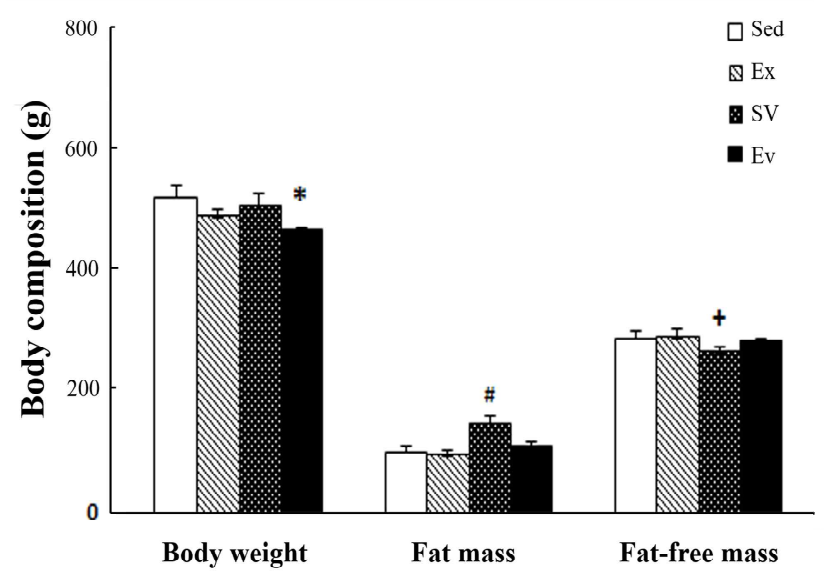

Fig. 1. Comparison of body composition.

Sed, sedentary group; Ex, exercise group; SV, Salvia miltiorrhiza vinegar group; EV, exercise+salvia miltiorthiza vinegar group.

*, Significantly different from Sed, Ex, SV $(\mathrm{p}<0.05)$.

\#, Significantly different from Sed, Ex, EV $(p<0.05)$

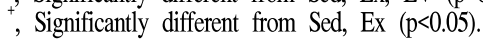

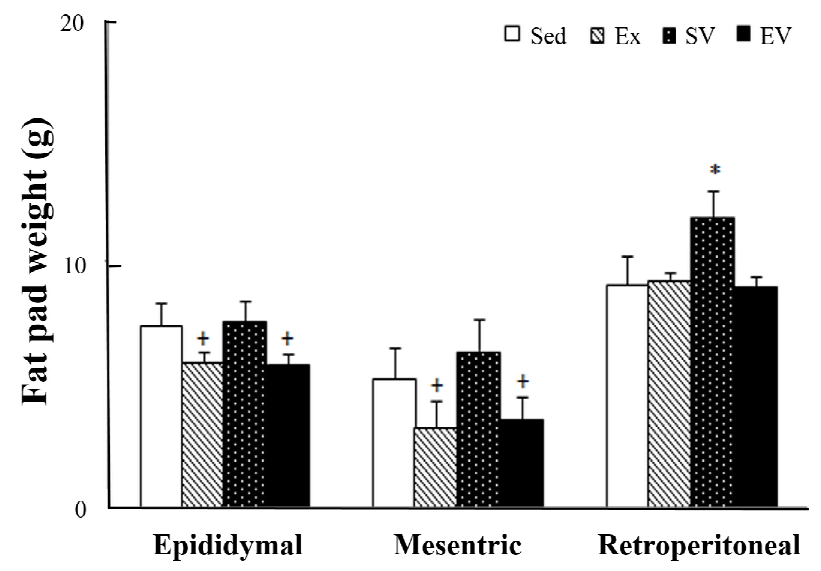

Fig. 2. Comparison of fat pad weight in body part.

Sed, sedentary group; Ex, exercise group; SV, Salvia miltiorthiza vinegar group; EV, exercise+Salvia miltiorthiza vinegar group.

*, Significantly different from Sed, Ex, Ev $(p<0.05)$.

+', Significantly different from Sed, SV $(\mathrm{p}<0.05)$. 
와는 다르게 단삼식초섭취군은 다른 3집단에 비해 retroperitoneal fat pad 양이 유의하게 증가한 것으로 나타났 다(p<0.05, Fig. 2). 본 연구의 결과와 유사하게 Chapados 등(25)은 고지방식이(총열량의 $42 \%$ ) 유도 비만 흰쥐를 대 상으로 중강도의 지구성 운동트레이닝이 내장지방 저장소 (mesenteric)와 비 내장지방 저장소(retroperitoneal)의 지방 분해에 미치는 영향을 분석한 결과, 운동트레이닝은 mesenteric fat pad의 지방 분해는 자극하는데 반해서 retroperitoneal fat pad의 지방분해에는 영향을 미치지 않는 것으로 보고하였다. 따라서 지구성 운동 시 내장지방의 현 저한 감소현상을 뒷받침할 수 있는 것으로 간주되며, 내장 지방은 비 내장지방 조직보다 고지혈증, 인슐린 저항성 및 2 형 당뇨병과 같은 대사기능 이상에 현저한 영향을 미치는 것으로 보고되어 왔다(26).

식이섭취량이 8 주간의 처치동안 집단 간 1 일 식이섭취열 량의 차이는 나타나지 않았다. 운동군의 1 일 식이섭취열량 이 복합처치군에 비해 높은 경향을 나타냈으나 통계적으로 유의한 차이는 없었다(Fig. 3). 식초는 수세기 동안 식품 방부제 및 다양한 질병에 대한 약제로 사용되어 왔으며, 식초의 항비만, 항고혈당 효과는 인간과 동물을 대상으로 실시된 다수의 연구를 통하여 제시되어 왔는데(27-29), 식 초의 전분소화력 간섭(30) 또는 위 배출 지연(27,29), 말초의 글루코스 흡수 및 글리코겐으로의 전환 및 포만감 증가(31) 등이 제시되었다. 그러나 본 연구에서 단삼식초섭취군의 1 일 식이섭취량이 다른 집단과 유사하게 나타남으로서 단 삼식초섭취에 의한 식옥 조절 가능성은 보다 계속적인 연구 가 요구되었다.

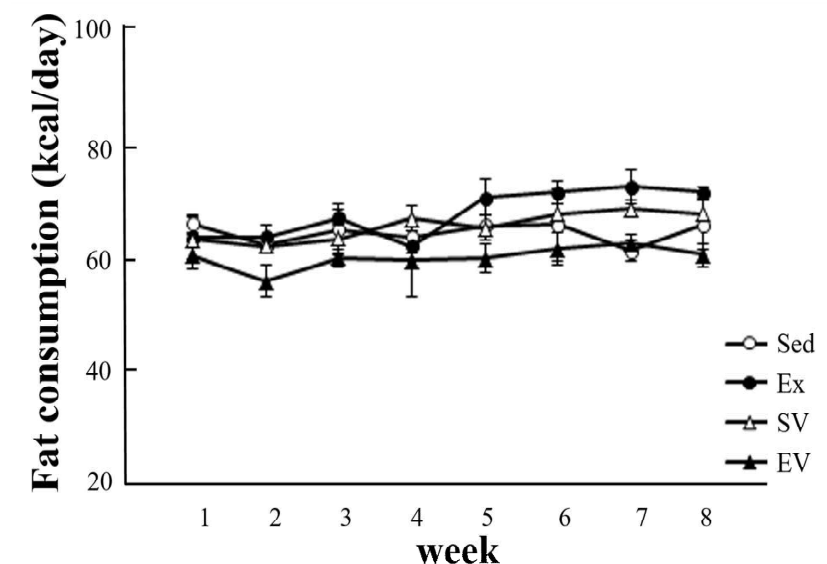

Fig. 3. Comparison of food consumption per day.

Sed, sedentary group; Ex, exercise group; SV, Salvia miltiorrhiza vinegar group; EV, exercise+Salvia miltiorthiza vinegar group.

\section{경구당 부하검사 및 총콜레스테롤 농도}

전신의 인슐린 감수성을 검증하기 위해서 경구당 부하검 사를 실시한 결과 8 주간의 지구성 운동군의 혈당 및 인슐린 반응이 좌업군에 비해서 유의하게 개선된 것으로 나타났으
며 $(\mathrm{p}<0.05)$, 복합처치군도 혈당 및 인슐린 반응이 유의하게 개선된 것으로 나타났다. 그러나 단삼식초섭취군은 혈당 및 인슐린 반응의 유의한 변화를 나타내지 않았다(Fig 4a, $4 \mathrm{~b})$. 즉 내장지방의 감소를 나타낸 지구성 운동군의 인슐린 저항성이 유의하게 감소하였으나, 내장지방의 변화가 나타 나지 않은 단삼식초섭취군은 인슐린 저항성의 현저한 개선 이 나타나지 않았다. 지구성 운동군 혹은 지구성 운동과 단삼식초섭취의 복합처치군에서 인슐린 저항성이 개선된 것은 지구성 운동과 단삼식초섭취의 긍정적인 결과로 간주 될 수 있으나 단삼식초섭취 만에 의한 개선된 결과가 나타 나지 않음으로서 단삼식초의 섭취효과는 분명하게 확인되 지 못했다.

8주간의 지구성 운동군은 좌업군에 비해서 혈청 콜레스 테롤 농도가 유의한 감소를 나타냈다( $\mathrm{p}<0.05)$. 그러나 단삼

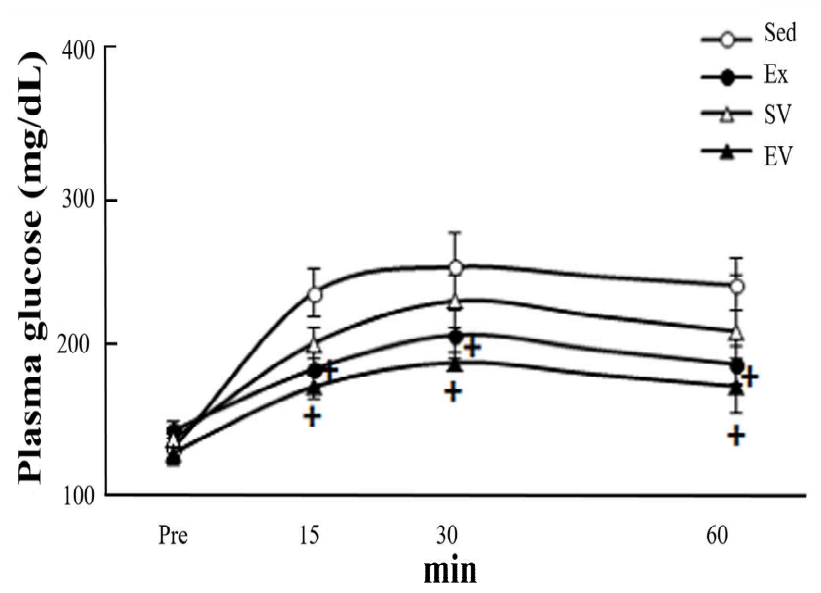

Fig 4a. Comparison of plasma glucose response to oral glucose tolerance test.

Sed, sedentary group; Ex, exercise group; SV, Salvia miltiorthiza vinegar group; EV, exercise+Salvia miltiorrhiza vinegar group.

+ , Significantly different from Sed, Ex group $(\mathrm{p}<0.05)$.

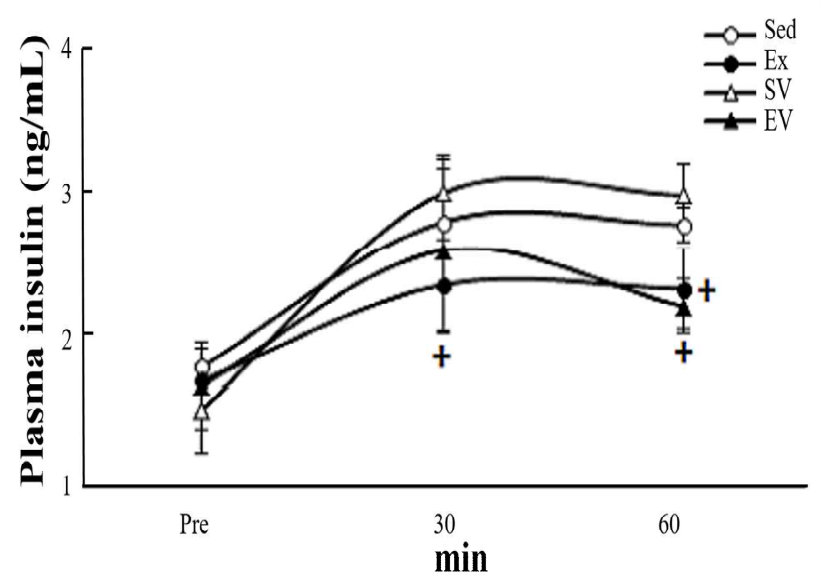

Fig 4b. Comparison of plasma insulin concentration in OGTT. Sed, sedentary group; Ex, exercise group; SV, Salvia miltiorrhiza vinegar group; EV, exercise+salvia miltiorthiza vinegar group.

${ }^{+}$, Significantly different from Sed, SV grop $(p<0.05)$. 
식초섭취군의 혈청 총콜레스테롤 농도는 좌업군과 유의한 차이를 나타내지 않았으며, 지구성 운동과 단삼식초섭취의 복합처치군도 유의한 차이를 나타내지 않았다(Fig. 5). 이러 한 결과는 지구성 운동이 혈중 지질농도에 미치는 긍정적인 효과가 단삼식초섭취의 복합처치로 인해서 상쇄된 것으로 도 해석될 수 있으나, 이와 관련된 보다 세부적인 원인에 대한 규명이 요구된다. 특히 단삼식초 섭취군의 신체구성 이 다른 집단과는 상반되게 나타났다는 것은 항 비만과 관련된 효과도 확인할 수 없음을 의미한다.

단삼이 대사성 증후군에 미치는 영향에 대한 대부분의 연구결과들은 비교적 긍정적인 결과들을 제시하고 있는데 반해서 본 연구에서는 대사성 증후군의 처치 가능성과 관련 된 기대했던 결과를 확인할 수 없었다. 그러나 본 연구에서 는 현상학적 접근만을 분석한 것으로서 그 세부적인 원인을 규명할 수 있는 분자생물학적 접근은 시도하지 않았기 때문 에 분명한 결론에 이르기는 어려운 것으로 생각된다. 최근 단삼이 AMPK 신호전달체계를 활성화 시키고, 성장호르몬 의 분비를 저해시킴으로서 항고혈당효과를 나타내며(32), Glut-1, GK 및 Glut-4와 같은 간 글리코겐 합성 유전자를 증가시키고 SREBP-1c, ACC, ATP-CL, ACS와 같은 지방 및 콜레스테롤 동화 작용 유전자를 감소시키는 것으로 보고 되었다(33). 이러한 근거를 바탕으로 추가적 분석 및 후속 연구를 실시하여 단삼의 항비만, 항고혈당 기전을 명확하 게 규명할 필요성이 있다.

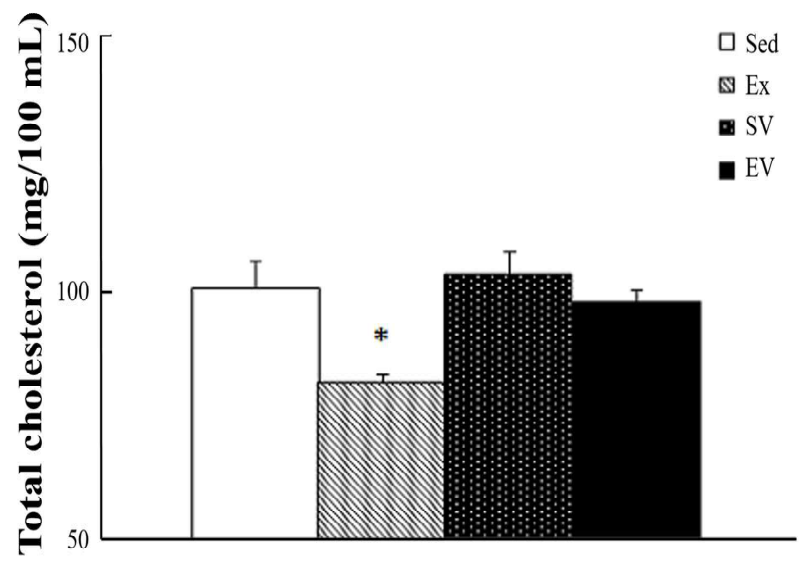

Fig 5. Comparison of total plasma cholesterol concentration.

Sed, sedentary group; Ex, exercise group; SV, Salvia miltiorrhiza vinegar group; EV, exercise+Salvia miltiorthiza vinegar group.

, Significantly different from Sed, SV, EV groups $(\mathrm{p}<0.05)$.

\section{요 약}

본 연구는 단삼식초 및 지구성 운동트레이닝이 고지방식 유도 비만 흰쥐의 신체구성 및 혈중 항목들의 농도 변화에 미치는 영향을 비교분석함으로서 대사성 증후군의 개선에
도움을 줄 수 있는 효과적인 방법을 모색하고자 실시되었 다. 10 주령 수컷 Wistar 흰쥐 40마리를 대상으로 8 주간 고지 방식 처치로 비만을 유도한 후 좌업군, 운동군, 단삼식초섭 취군, 운동군+단삼식초섭취 복합처치군 등으로 무선, 배정 하여 총 8 주간 운동 및 식이처치를 실시하였으며, 체중 및 신체구성, 식이섭취량, 경구당 부하검사 및 혈중 콜레스테 롤 농도 등을 측정하였다. 8 주간의 단삼식초섭취는 지구성 운동과 병행할 경우 체중감소 및 인슐린 저항성의 개선효과 를 확인할 수 있었다. 그러나 단삼식초섭취만 처치할 경우 오히려 체지방량을 증가시키고 제지방량은 감소시켰으며, 인슐린 저항성을 현저하게 개선시키지 않는 것으로 나타났 다. 또한 지구성 운동과의 병행 시도의 경우에도 운동효과 를 배제한 부가적인 효과가 나타나지 않았으며, 혈중 지질 에 있어서는 운동의 효과마저 둔화시키는 것으로 나타났 다. 따라서 단삼식초섭취에 따른 항고혈당, 항비만 효과는 확인될 수 없었으며, 추후 분자생물학적 분석에 의한 기전 과 관련된 원인분석을 통해서 보다 명확한 결과를 제시할 수 있을 것으로 생각된다.

\section{감사의 글}

본 결과물은 농림축산식품부의 재원으로 농림수산식품 기술기획평가원의 고부가가치식품기술개발사업의 지원 을 받아 연구되었음(314072-3).

\section{References}

1. Tahrani AA, Piya MK, Kennedy A, Barnett AH (2010) Glycaemic control in type 2 diabetes: Targets and new therapies. Pharmacol Ther, 125, 328-361

2. Nolan CJ, Ruderman NB, Kahn SE, Pedersen O, Prentki M (2015) Insulin resistance as a physiological defense against metabolic stress: Implications for the management of subsets of type 2 diabetes. Diabetes, 64, 673-686

3. Shaw JE, Sicree RA, Zimmet PZ (2010) Global estimates of the prevalence of diabetes for 2010 and 2030. Diabetes Res Clin Pract, 87, 4-14

4. Yang W, Lu J, Weng J, Jia W, Ji L, Xiao J, Shan Z, Liu J, Tian H, Ji Q, Zhu D, Ge J, Lin L, Chen L, Guo X, Zhao Z, Li Q, Zhou Z, Shan G, He J (2010) Prevalence of diabetes among men and women in China. $\mathrm{N}$ Engl J Med, 362, 1090-1101

5. Tahrani AA, Barnett AH, Bailey CJ (2016) Pharmacology and therapeutic implications of current drugs for type 2 diabetes mellitus. Nat Rev Endocrinol, 12, 566-592 
6. Prabhakar PK, Doble M (2008) A target based therapeutic approach towards diabetes mellitus using medicinal plants. Curr Diabetes Rev, 4, 291-308

7. Xu X, Liang T, Lin X, Wen Q, Liang X, Li W, Qin F, Zheng N, Ming J, Huang R (2015) Effect of the total extract of a verrhoacarambola (oxalidaceae) root on the expression levels of TLR-4 and NF-kB in streptozotocininduced diabetic mice. Cell Physiol Biochem, 36, 2307-2316

8. Shon YH, Cho HJ, Kim MK, Jung EJ, Nam KS (2007) Effect of ethanol extract from Salvia miltiorrhiza on chemoprevention and metastasis of breast cancer. Kor J Pharmacogn, 38, 62-66

9. Ji XY, Tan BKH, Zhu YZ (2000) Salvia miltiorrhiza and ischemic diseases. Acta Pharmacol Sin, 21, 1089 1094

10. Ng CF, Koon CM, Cheung DWS, Lam MY, Leung PC, Lau CBS, Fung KP (2011) The anti-hypertensive effect of Danshen (Salvia miltiorrhiza) and Gegen (Pueraria lobata) formula in rats and its underlying mechanisms of vasorelaxation. J Ethnopharmacol, 137, 1366 - 1372

11. Pan C, Huo Y, An X, Singh G, Chen M, Yang Z, Pu J, Li J (2012) Panax notoginseng and its components decreased hypertension via stimulation of endothelialdependent vessel dilatation. Vasc Pharmacol, 56, 150-158

12. Wing-Shing Cheung D, Koon CM, Ng CF, Leung PC, Fung KP, Kar-Sing Poon S, Bik-San Lau C (2012) The roots of Salvia miltiorrhiza (Danshen) and Pueraria lobata (Gegen) inhibit atherogenic events: a study of the combination effects of the 2-herb formula. J Ethnopharmacol, $143,859-866$

13. Cheng GC, Lee JY, Kim DC, Suh SO, Hwang WI (2000) Inhibitory effect of Salvia miltiorrhiza extract on growth of some cancer cells. J Korean Soc Food Sci Nutr, 29, 726-731

14. Cao W, Guo XW, Zheng HZ, Li DP, Jia GB, Wang J (2012) Current progress of research on pharmacologic actions of salvianolic acid B. Chin J Integr Med, 18, 316-320

15. Lin C, Liu Z, Lu Y, Yao Y, Zhang Y, Ma Z, Kuai M, Sun X, Sun S, Jing Y, Yu L, Li Y, Zhang Q, Bian H (2016) Cardioprotective effect of salvianolic acid B on acute myocardial infarction by promoting autophagy and neovascularization and inhibiting apoptosis. J Pharm Pharmacol, 68, 941-952

16. Lv H, Wang L, Shen J, Hao S, Ming A, Wang X, Su F, Zhang Z (2015) Salvianolic acid B attenuates apoptosis and inflammation via SIRT1 activation in experimental stroke rats. Brain Res Bull, 115, 30-36

17. Huang M, Xie Y, Chen L, Chu K, Wu S, Lu J, Chen X, Wang Y, Lai X (2012) Antidiabetic effect of the total polyphenolic acids fraction from Salvia miltiorrhiza Bunge in diabetic rats. Phytother Res, 26, 944-948

18. Wang P, Xu S, Li W, Wang F, Yang Z, Jiang L, Wang Q, Huang M, Zhou P (2014) Salvianolic acid B inhibited PPARy expression and attenuated weight gain in mice with high-fat diet-induced obesity. Cell Physiol Biochem, 34, 288-298

19. Huang M, Wang $\mathrm{P}, \mathrm{Xu} \mathrm{S}, \mathrm{Xu} \mathrm{W}, \mathrm{Xu} \mathrm{W}, \mathrm{Chu} \mathrm{K}, \mathrm{Lu}$ J (2015) Biological activities of salvianolic acid B from Salvia miltiorrhiza on type 2 diabetes induced by high-fat diet and streptozotocin. Pharm Biol, 53, 1058-1065

20. Raoufi S, Baluchnejadmojarad T, Roghani M, Ghazanfari T, Khojasteh F, Mansouri M (2015) Antidiabetic potential of salvianolic acid B in multiple low-dose streptozotocininduced diabetes. Pharm Biol, 53, 1803-1809

21. Yamashita H, Fujisawa K, Ito E, Idei S, Kawaguchi N, Kimoto M, Hiemori M, Tsuji H (2007) Improvement of obesity and glucose tolerance by acetate in type 2 diabetic Otsuka Long-Evans Tokushima Fatty (OLETF) rats. Biosci Biotechnol Biochem, 71, 1236 - 1243

22. Hancock CR, Han DH, Chen M, Terada S, Yasuda T, Wright DC, Holloszy JO (2008) High-fat diets cause insulin resistance despite an increase in muscle mitochondria. Proc Natl Acad Sci USA, 105, 7815-7820

23. Lee JH, Cho HD, Jeong JH, Lee MK, Jeong YK, Shim $\mathrm{KH}$, Seo KI (2013) New vinegar produced by tomato suppresses adipocyte differentiation and fat accumulation in 3T3-L1 cells and obese rat model. Food Chem, 141, 3241-3249

24. Ivy JL, Young JC, McLane JA, Fell RD, Holloszy JO (1983) Exercise training and glucose uptake by skeletal muscle in rats. J Appl Physiol, 55, 1393-1396

25. Chapados N, Collin P, Imbeault $P$, Corriveau $P$, Lavoie JM (2008) Exercise training decreases in vitro stimulated lipolysis in a visceral (mesenteric) but not in the retroperitoneal fat depot of high-fat-fed rats. Br J Nutr, $100,518-525$

26. Votruba SB, Jensen MD (2007) Regional fat deposition as a factor in FFA metabolism. Ann Rev Nutr, 27, 149 163

27. Brighenti F, Castellani G, Benini L, Casiraghi MC, Leopardi E, Crovetti R, Testolin G (1995) Effect of neutralized and native vinegar on blood glucose and 
acetate responses to a mixed meal in healthy subjects.

Eur J Clin Nutr, 49, 242-247

28. Ebihara K, Nakajima A (1998) Effect of acetic acid and vinegar on blood glucose and insulin responses to orally administered sucrose and starch. Agric Biol Chem, 52, 1311-1322

29. Liljeberg H, Bjorck I (1998) Delayed gastric emptying rate may explain improved glycaemia in healthy subjects to a starchy meal with added vinegar. Eur J Clin Nutr, 52, 368-371

30. Ogawa N, Satsu H, Watanabe H, Fukaya M, Tsukamoto Y, Miyamoto Y, Shimizu M (2000) Acetic acid suppresses the increase in disaccharidase activity that occurs during culture of Caco-2 cells. J Nutr, 130, 507-513
31. Fushimi T, Sato Y (2005) Effect of acetic acid feeding on the circadian changes in glycogen and metabolites of glucose and lipid in liver and skeletal muscle of rats. Br J Nutr, 94, 714-719

32. Qiang G, Yang X, Shi L, Zhang H, Chen B, Zhao Y, Zu M, Zhou D, Guo J, Yang H, Zhang L, Du G (2015) Antidiabetic effect of salvianolic acid a on diabetic animal models via AMPK activation and mitochondrial regulation. Cell Physiol Biochem, 36, 395-408

33. Xie P, Duan Y, Guo X, Hu L, Yu M (2015) SalA attenuates hypoxia-induced endothelial endoplasmic reticulum stress and apoptosis via down-regulation of VLDL receptor expression. Cell Physiol Biochem, 35, $17-28$ 